\title{
Serum DHEA-S Is a Predictive Parameter of Abiraterone Acetate in Patients with Castration-resistant Prostate Cancer
}

\author{
KOTARO SUZUKI, MARIKO SAKAMOTO, TOMOAKI TERAKAWA, JUNYA FURUKAWA, \\ KENICHI HARADA, NOBUYUKI HINATA, YUZO NAKANO and MASATO FUJISAWA \\ Division of Urology, Kobe University Graduate School of Medicine, Kobe, Japan
}

\begin{abstract}
Background/Aim: There is no definitive biomarker that predicts the effectiveness of abiraterone acetate. The objective of this study was to investigate whether dehydroepiandrosterone sulfate (DHEA-S) predicts the effectiveness of abiraterone acetate. Materials and Methods: This study included a total of 28 consecutive patients. The optimal cutoff value of DHEA-S for predicting the PSA response was calculated by receiver operating characteristic (ROC) analysis. The Cox proportional hazards model was performed to determine the predictive factors for the susceptibility to abiraterone acetate. Results: Serum DHEA-S at baseline intercorrelated with the PSA response (correlation coefficient: -0.516). The optimal cutoff value of serum DHEA-S at baseline was $47.4 \mathrm{ug} / \mathrm{dl}$ in predicting $>50 \%$ PSA decline. Serum PSA and serum DHEA-S at baseline were identified as significant factors for predicting PSA progression-free survival ( $p=0.010$ and $p=0.003$, respectively). Conclusion: Serum DHEA-S at baseline may be a biomarker for predicting the prognosis of CRPC patients treated with abiraterone acetate.
\end{abstract}

Prostate cancer that initially responds to treatment, but progresses despite suppression of serum testosterone is called castration-resistant prostate cancer (CRPC), and is invariably fatal $(1,2)$. The management of metastatic CRPC (mCRPC) involves sequential therapies, and five agents have shown a survival benefit in randomized clinical studies since 2010 (3-9).

Abiraterone acetate is a selective inhibitor of androgen biosynthesis that potently blocks cytochrome P450 c17 (CYP17), a critical enzyme in testosterone synthesis, has $17 \alpha$-hydroxylase/17, 20-lyase inhibitory properties, and

Correspondence to: Kotaro Suzuki, Division of Urology, Kobe University Graduate School of Medicine, 7-5-1 Kusunoki-cho, Chuo-ku 650-0017 Kobe, Japan. Tel: +81 783826155, Fax: +81 783826169, e-mail: pikataro1012@gmail.com

Key Words: Abiraterone acetate, DHEA-S, castration-resistant prostate cancer, PSA response, PSA progression-free survival. inhibits testicular, adrenal, and intratumor androgen synthesis $(10,11)$.

Although two randomized phase III trials (COU-AA-301 and COU-AA-302) have demonstrated that abiraterone acetate plus prednisone improves overall survival (OS) in patients with mCRPC, both pretreated with chemotherapy and chemotherapy-naïve, primary resistance to abiraterone acetate remains a clinical challenge $(5,9)$. Nevertheless, there is still no definitive biomarker for predicting patients with primary resistance to abiraterone acetate.

One important mechanism mediating CRPC is the intratumoral conversion of weak adrenal androgens, including dehydroepiandrosterone (DHEA), DHEA sulfate (DHEA-S), and androstenedione, into the androgen receptor (AR) ligands testosterone and dihydrotestosterone (DHT) (12). Abiraterone acetate blocks this conversion by blocking the production of DHEA. A retrospective analysis of COUAA-301 demonstrated that DHEA-S at the induction of abiraterone acetate was prognostic for OS (13). However, the association of DHEA-S at baseline and the clinical response to abiraterone acetate is still unknown. Therefore, the objective of this study was to investigate whether DHEA-S at baseline could predict the effectiveness of abiraterone acetate in patients with CRPC.

\section{Materials and Methods}

Patients. This study included a total of 28 consecutive patients with CRPC treated with abiraterone acetate plus prednisone at the Kobe University hospital in Japan. All of these patients showed disease progression after the treatment with orchiectomy or medical castration. Patients were recruited between September 2014 and December 2016. Informed consent for performing the present study was obtained from all patients, and the study design was approved by the Research Ethics Committee of our institution (No.170217).

Treatment and procedures. Abiraterone acetate was administered orally in 28-day cycles at $1000 \mathrm{mg}$ per day with prednisone at 10 $\mathrm{mg}$ per day until disease progression or unacceptable toxicity. Patients were assessed at the beginning of each 28-day cycle for safety and response. Computed tomography (CT) and bone scintigraphy were performed at baseline. PSA measurements were 
taken at baseline and with each cycle of treatment. DHEA-S measurements were taken at baseline.

The primary endpoint was PSA progression-free survival (PSAPFS). PSA progression was defined as a $25 \%$ PSA increase and an absolute increase of $2 \mathrm{ng} / \mathrm{ml}$ from the nadir, or for patients without a PSA decline, a $25 \%$ PSA increase and an absolute increase of 2 $\mathrm{ng} / \mathrm{ml}$ from baseline, according to Prostate Cancer Working Group (PCWG2)

Measurement of DHEA-S. DHEA-S was measured by chemiluminescent immunoassays on a Beckman Access Immunoassay system (UniCel DxI 800; Beckman Coulter, Inc., Brea, CA, USA ). All blood samples were taken between 9 and 15 $\mathrm{h}$ to minimize the influence of daily DHEA-S variations.

Statistical analysis. The relationship between serum DHEA-S at the induction of abiraterone acetate and the PSA-PFS of abiraterone acetate were investigated. The optimal cut-off value of DHEA-S for predicting a PSA response, defined as $\geq 50 \%$ decline, was calculated by receiver operating characteristic analysis. Univariate analysis among the variables was assessed using a two-sample Student's t test and the $\chi^{2}$ test, as appropriate. PSA-PFS was estimated by the Kaplan-Meier method and assessed with a log-rank test. The Cox proportional hazards model was used to determine the predictive factors for the susceptibility to abiraterone acetate.

All statistical analyses were performed with EZR (Saitama Medical Center, Jichi Medical University, Saitama, Japan) (14), which is a graphical user interface for $\mathrm{R}$ (The R Foundation for Statistical Computing, Vienna, Austria). More precisely, it is a modified version of $\mathrm{R}$ commander designed to add statistical functions frequently used in biostatistics. Each test was two-sided, and $p<0.05$ was considered significant.

\section{Results}

Demographic information and clinical characteristics of 28 patients are summarized in Table I. The median level of serum DHEA-S was $25.9 \mu \mathrm{g} / \mathrm{dl}$, which was almost equivalent to that of a previous report (13).

The correlation between serum DHEA-S at baseline and PSA decline after treatment with abiraterone acetate was analyzed. There was a moderate correlation between these two factors (correlation coefficient: -0.516) (Figure 1). Then, we hypothesized that patients with a higher value of serum DHEA-S at baseline might have better PSA response, defined as a $\geq 50 \%$ decline.

Next, we investigated the optimal cutoff value of serum DHEA-S at baseline for predicting the PSA response in the receiver operating characteristic (ROC) analysis. The optimal cutoff value was $47.4 \mu \mathrm{g} / \mathrm{dl}$ (sensitivity: 0.727 , specificity: 0.765) (Figure 2). Thus, the patients were divided into two groups, serum DHEA-S at baseline $<47 \mu \mathrm{g} / \mathrm{dl}$ or $\geq 47 \mu \mathrm{g} / \mathrm{dl}$. Demographic information and clinical characteristics of these two groups are summarized in Table II. There were no significant differences in baseline characteristics between the two groups including patient age, ECOG performance status, Gleason score of biopsy, serum PSA at baseline, site of
Table I. Patients' characteristics.

\begin{tabular}{lc}
\hline $\mathrm{n}=28$ & \\
\hline Periods of observation, median (range), months & $18.5(4.1-45.8)$ \\
Age, median (range), years & $77.5(61-88)$ \\
ECOG performance status, $\mathrm{n}(\%)$ & \\
0 & $15(53.6)$ \\
$\geq 1$ & $13(46.4)$ \\
Gleason Score, $\mathrm{n}(\%)$ & \\
$\leq 7$ & $4(14.3)$ \\
$\geq 8$ & $24(85.7)$ \\
PSA at baseline, median (range), ng/ml & $12.5(1.05-943)$ \\
Site of disease, $\mathrm{n}(\%)$ & \\
None & $5(17.9)$ \\
Bone & $20(71.4)$ \\
Lymph node & $4(14.3)$ \\
Visceral & $6(21.4)$ \\
Post docetaxel, $\mathrm{n}(\%)$ & \\
$\quad$ No & $22(78.6)$ \\
Yes & $6(21.4)$ \\
Duration of prior ADT $\geq 12$ months, $\mathrm{n}(\%)$ & $24(85.7)$ \\
Serum DHEA-S at baseline, median (range), $\mu \mathrm{g} / \mathrm{dl}$ & $25.9(2.0-314.5)$ \\
\end{tabular}

ECOG: Eastern Cooperative Oncology Group; PSA: prostate-specific antigen; ADT: androgen deprivation therapy; DHEA-S: dehydroepiandrosterone sulfate.

disease, prior docetaxel treatment, and duration of prior androgen-deprivation therapy (ADT). The waterfall plots of PSA decline in treatment with abiraterone acetate showed that patients with $\geq 47 \mu \mathrm{g} / \mathrm{dl}$ of serum DHEA-S at baseline had a significantly better PSA response than patients with $<47 \mu \mathrm{g} / \mathrm{dl}(p<0.001)$ (Figure 3).

The association between serum DHEA-S at baseline and the clinical outcome of treatment with abiraterone acetate were also evaluated. PSA progression-free survival (PSA-PFS) and OS curves based on serum DHEA-S stratified at $47 \mu \mathrm{g} / \mathrm{dl}$ are shown in Figure $4 a, b$. Although there was no significant difference in OS ( $p=0.45)$, patients with $\geq 47 \mu \mathrm{g} / \mathrm{dl}$ of serum DHEA-S at baseline had a significantly longer PSA-PFS than patients with $<47 \mu \mathrm{g} / \mathrm{dl}$ (median PSA-PFS were 28.4 months and 3.4 months, respectively; $p=0.006$ ). As shown in Table III, serum PSA and serum DHEA-S at baseline were identified as significant factors for predicting PSA-PFS in the Cox proportional hazards model (hazard ratio 3.47 and 0.17 ; $p=0.010$ and $p=0.003$, respectively).

These results suggested that patients with a high value of serum DHEA-S at baseline may have a better PSA response and longer PSA-PFS when treated with abiraterone acetate.

\section{Discussion}

Here, it was demonstrated that patients with a high value of serum DHEA-S had a better PSA response and that a high value of serum DHEA-S and serum PSA at baseline 


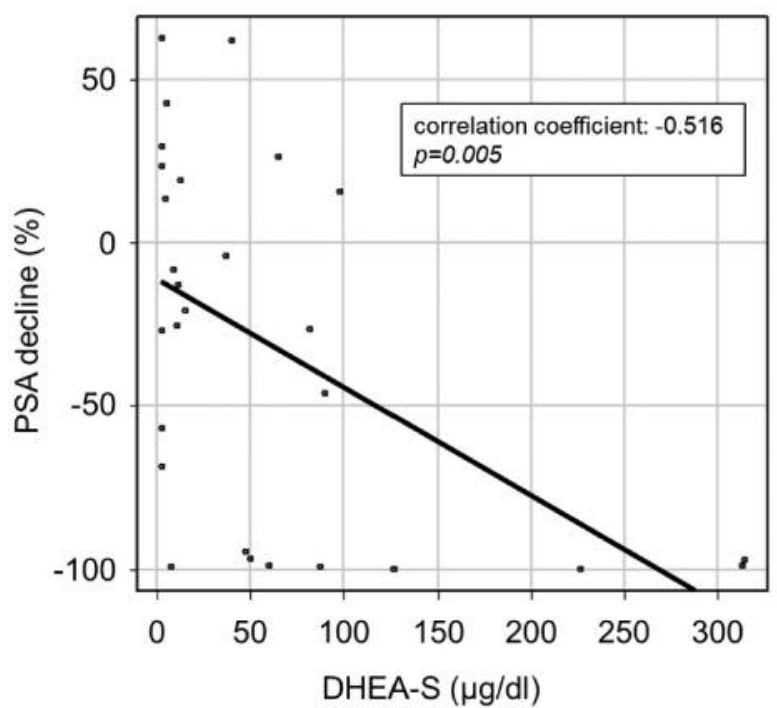

Figure 1. Correlation analysis between the concentration of serum DHEA-S at baseline and the PSA response after induction of abiraterone acetate.

correlated significantly with longer PSA-PFS in treatment with abiraterone acetate.

Although abiraterone acetate has commonly been used in androgen receptor-axis-targeted (ARAT) therapy with improvement of clinical outcomes of CRPC, primary resistance to this agent remains a clinical challenge. In a clinical trial with abiraterone acetate, $35 \%$ of patients, at most, showed radiographic progression and PSA progression within the first 3 months of these therapies $(5,9,15,16)$. Therefore, identification of a biomarker for predicting patients with primary resistance is an increasing clinical concern. Although the mechanisms of resistance to abiraterone acetate have been studied including intratumor androgen biosynthesis upregulation, increased expression of ligand independent AR splice variants $(17,18)$, and promiscuous activation of AR by alternative ligands $(19,20)$, resistance to abiraterone acetate is inevitable and identification of clinically validated predictive biomarkers remains elusive (21).

Adrenal androgen may be a biomarker for predicting the clinical outcome of treatment with abiraterone acetate. In CRPC patients previously treated with ketoconazole, patients with a high DHEA value at baseline had a better PSA response and longer PFS (22). A retrospective analysis of COU-AA-301 demonstrated that low serum DHEA-S at baseline was predictive of worse cancer-specific survival among metastatic CRPC (13). DHEA and DHEA-S are adrenal androgens that are converted into testosterone and

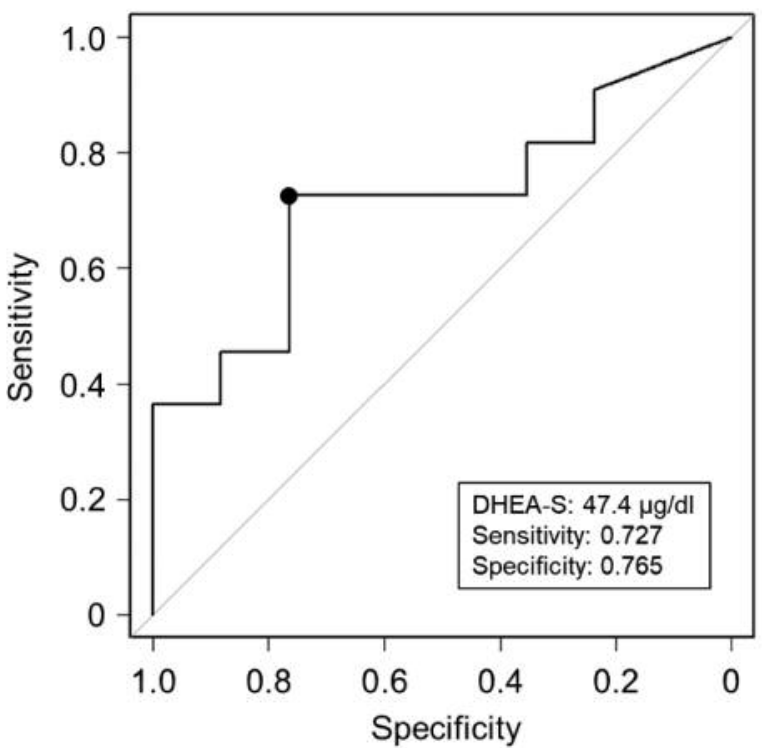

Figure 2. Receiver operating characteristic curve (ROC) of the concentration of serum DHEA-S for predicting $\geq 50 \%$ PSA decline with the treatment of abiraterone acetate.

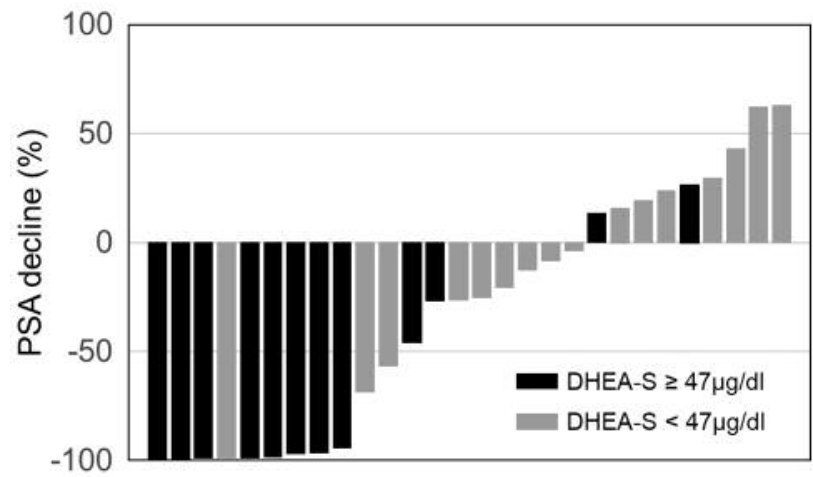

Figure 3. Waterfall plot representing the percentage of the best response in PSA after the induction of abiraterone acetate.

DHT in the prostate. DHEA is a product of de novo steroidogenesis, which begins with cholesterol and CYP17A1, the target of abiraterone acetate that regulates successive reactions to convert pregnenolone into DHEA (23). Tamae et al. found that although serum DHEA was significantly reduced in CRPC patients treated with abiraterone acetate, a significant amount of DHEA-S persisted and this persistent pool of DHEA-S could serve as a precursor for conversion into testosterone and DHT in prostate cancer (24), which suggests that DHEA-S may be a 
Table II. Patients' characteristics based on serum DHEA-S at baseline.

\begin{tabular}{|c|c|c|c|}
\hline \multirow[b]{2}{*}{$\mathrm{n}=28$} & \multicolumn{2}{|c|}{ DHEA-S } & \multirow[b]{2}{*}{$p$-Value } \\
\hline & $<47 \mu \mathrm{g} / \mathrm{dl}(\mathrm{n}=16)$ & $\geq 47 \mu \mathrm{g} / \mathrm{dl}(\mathrm{n}=12)$ & \\
\hline Periods of observation, median (range), months & $18.5(4.4-45.8)$ & $15.8(4.1-39.3)$ & 0.345 \\
\hline Age, median (range), years & $75.5(61-87)$ & $77(61-88)$ & 0.754 \\
\hline \multicolumn{4}{|l|}{ ECOG performance status, n (\%) } \\
\hline 0 & $8(50.0)$ & $7(58.3)$ & 0.718 \\
\hline$\geq 1$ & $8(50.0)$ & $5(41.7)$ & \\
\hline \multicolumn{4}{|l|}{ Gleason Score, n (\%) } \\
\hline$\leq 7$ & $1(6.3)$ & $3(25.0)$ & 0.285 \\
\hline$\geq 8$ & $15(93.7)$ & $9(75.0)$ & \\
\hline PSA at baseline, median (range), $\mathrm{ng} / \mathrm{ml}$ & $13.6(1.05-943)$ & $9.4(1.33-342)$ & 0.473 \\
\hline Site of disease, $n(\%)$ & & & 1.000 \\
\hline None & $3(18.8)$ & $2(16.7)$ & 1.000 \\
\hline Bone & $11(68.8)$ & $9(75.0)$ & 0.113 \\
\hline Lymph node & $4(25.0)$ & $0(0.0)$ & 0.354 \\
\hline Visceral & $2(12.5)$ & $4(33.3)$ & \\
\hline \multicolumn{4}{|l|}{ Post docetaxel, n (\%) } \\
\hline No & $11(68.8)$ & $11(91.7)$ & 0.196 \\
\hline Yes & $5(31.2)$ & $1(8.3)$ & \\
\hline Duration of prior ADT $\geq 12$ months, $\mathrm{n}(\%)$ & $14(87.5)$ & $10(83.3)$ & 1.000 \\
\hline
\end{tabular}

ECOG: Eastern Cooperative Oncology Group; PSA: prostate-specific antigen; ADT: androgen deprivation therapy; DHEA-S: dehydroepiandrosterone sulfate.

Table III. Uni- and multivariate analyses of several parameters for predicting PSA-PFS.

\begin{tabular}{|c|c|c|c|c|}
\hline \multirow[b]{2}{*}{$\mathrm{n}=28$} & \multicolumn{2}{|c|}{ Univariate analysis } & \multicolumn{2}{|c|}{ Multivariate analysis } \\
\hline & HR $(95 \% \mathrm{CI})$ & $p$-Value & HR $(95 \% \mathrm{CI})$ & $p$-Value \\
\hline Age $(\geq 70 v s .<70)$, years & $1.35(0.47-3.82)$ & 0.576 & - & - \\
\hline ECOG performance status ( $\geq 1 v s .0$ ) & $1.34(0.54-3.33)$ & 0.528 & - & - \\
\hline Gleason score $(\geq 8 v s . \leq 7)$ & $3.47(0.46-26.3)$ & 0.228 & - & - \\
\hline PSA at baseline $(\geq 20 v s .<20), \mathrm{ng} / \mathrm{ml}$ & $3.67(1.45-9.24)$ & 0.006 & $3.47(1.34-9.00)$ & 0.010 \\
\hline Duration of prior ADT ( $\geq 12 \mathrm{vs}<12)$, months & $0.52(0.14-1.92)$ & 0.327 & - & - \\
\hline Post docetaxel (yes $v s$. no) & $2.13(0.79-5.71)$ & 0.134 & - & - \\
\hline Bone metastasis at baseline (yes vs. no) & $0.85(0.30-2.40)$ & 0.761 & - & - \\
\hline Visceral metastasis at baseline (yes $v s$. no) & $0.86(0.28-2.59)$ & 0.783 & - & - \\
\hline Serum DHEA-S at baseline $(\geq 47 v s .<47), \mu \mathrm{g} / \mathrm{dl}$ & $0.17(0.05-0.52)$ & 0.008 & $0.17(0.05-0.54)$ & 0.003 \\
\hline
\end{tabular}

PSA-PFS: Prostate-specific antigen progression free survival; ECOG: Eastern Cooperative Oncology Group; ADT: androgen deprivation therapy; DHEA-S: dehydroepiandrosterone sulfate; HR: hazard ratio; CI: confidence interval.

more optimal biomarker for predicting the clinical outcomes of treatment with abiraterone acetate than DHEA.

Yano et al. showed that low serum DHEA-S predicted poor responsiveness to hormone therapy in patients with hormonenaïve metastatic prostate cancer (25). Miyoshi et al. reported that a low DHEA level was associated with a higher Gleason score and more advanced clinical stage in patients with hormone-naïve prostate cancer (26). Interestingly, Lauren et al. demonstrated that statins block DHEA-S uptake into prostate cancer cells by competitively binding to SLCO2B 1 in vitro, and that the use of statins during androgendeprivation therapy (ADT) in a retrospective analysis was associated with a significantly longer time to progression (TTP) (27). These findings suggest that DHEA and DHEA-S may be biomarkers for predicting prognosis not only in CRPC but in hormone-naïve prostate cancer.

We demonstrated that a high value of serum DHEA-S at baseline correlated significantly with a longer PSA-PFS, but 
a

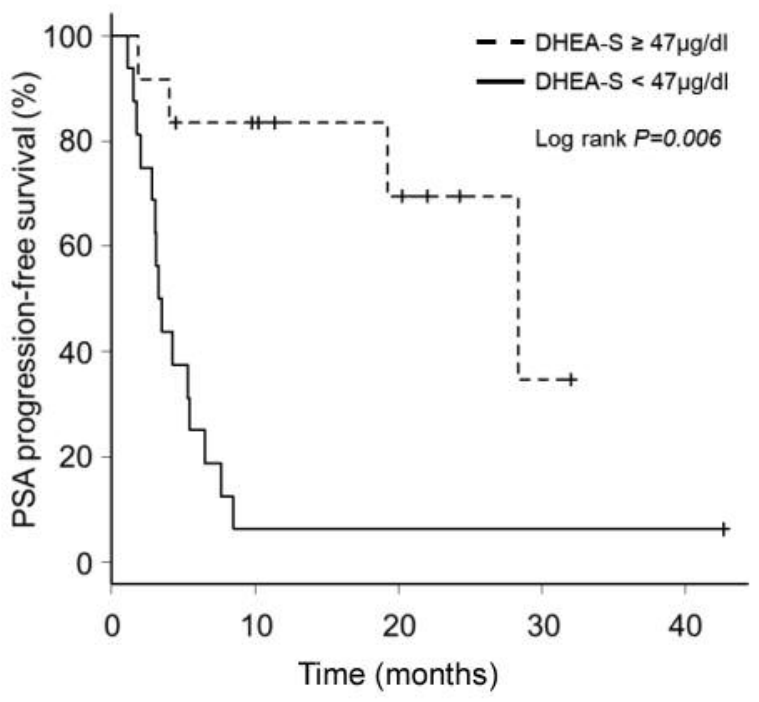

b

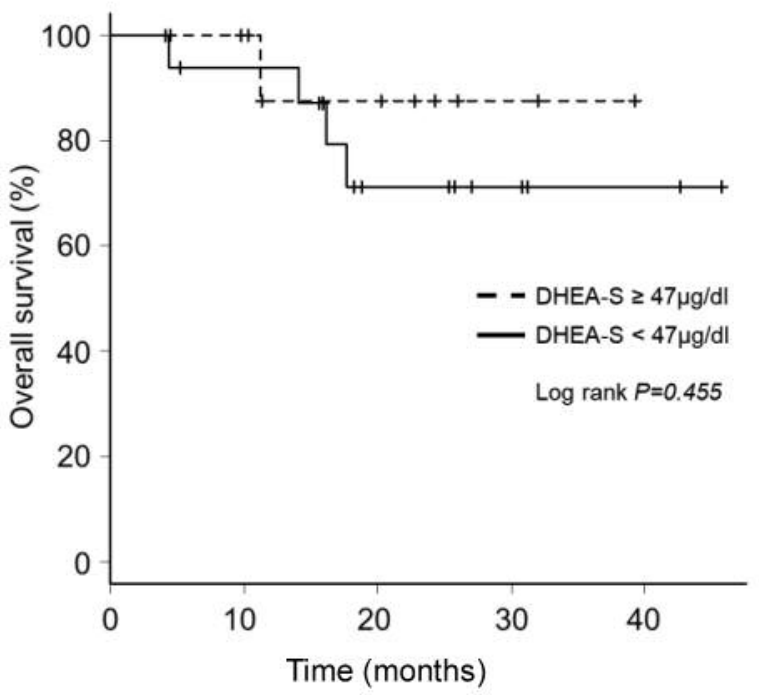

Figure 4. Kaplan-Meier estimates of (a) PSA progression-free survival and (b) overall survival among castration-resistant prostate cancer patients with the indicated concentrations of DHEA-S at the induction of abiraterone acetate.

a previous report demonstrated that there was no significant association between a baseline value of DHEA-S and PFS (28). This contradiction may be caused by the way of defining the cutoff value of serum DHEA-S. In general, because the value of serum DHEA-S decreases with age (29) and after prior ADT (30), there is no reference value of serum DHEA-S in our patients. Although the median value was defined as the cutoff value in this previous report, we defined $47 \mu \mathrm{g} / \mathrm{dl}$ as the cutoff value with ROC analysis to exactly reflect the PSA response, which was higher than the median value $25.9 \mu \mathrm{g} / \mathrm{dl}$. This finding suggested that the cutoff value should be high enough to reflect the PSA response in future clinical applications, and further larger scale studies may provide a more predictive cutoff value.

Patients with a high value of serum PSA at baseline also had a significantly longer PSA-PFS in treatment with abiraterone acetate. Hiroshige et al. reported that a high value of serum PSA at baseline prior to treatment with abiraterone acetate was a prognostic factor of worse OS in patients with CRPC (31). A retrospective analysis of COU-AA 302 demonstrated that it was a prognostic factor of shorter radiographic progression-free survival (32). In addition, this factor has also been reported as a biomarker for predicting clinical outcomes of several therapeutic agents $(33,34)$, which suggests that serum PSA at baseline may be a biomarker for CRPC rather than for abiraterone acetate.

In sequential ARAT therapy for CRPC, several previous reports demonstrated that enzalutamide, a new non-steroidal antiandrogen, achieved only a modest response rate in patients progressing after abiraterone acetate (35-37). The impact of serum DHEA-S on subsequence enzalutamide is of great interest. More recently, abiraterone acetate has been used in various stage of therapeutic strategy for advanced prostate cancer, such as in metastatic hormone-naïve state (38) and in combination with radiotherapy (39-41). Serum DHEA-S may also be a biomarker for predicting the responses of these therapies.

The main limitations of the present study were the retrospective non-randomized analysis, the small cohort size including both docetaxel naïve and treated, and the relatively short follow-up time. There is a possibility that these limitations may have influenced our data on OS, which was contrary to the sub-analysis of COU-AA-301. Furthermore, the association between serum DHEA-S at baseline and radiographic progression were not evaluated. The CLEIA method was used to evaluate serum DHEA-S, but liquid chromatography coupled to tandem mass spectrometry (LCMS/MS) was used in previous reports $(13,26)$, which may have resulted in differences in sensitivity to DHEA-S. In addition, we should more strictly manage the time to take blood samples because there is daily variation in DHEA-S.

In conclusion, patients with a high value of serum DHEA-S had a better PSA response and longer PSA-PFS in the treatment with abiraterone acetate, which suggests that serum DHEA-S at baseline may be a biomarker for predicting the effectiveness of abiraterone acetate in patients with CRPC.

\section{Conflicts of Interest}

The Authors declare that they have no conflicts of interest. 


\section{References}

1 Feldman BJ and Feldman D: The development of androgenindependent prostate cancer. Nat Rev Cancer 1: 34-45, 2001.

2 Pienta KJ and Bradley D: Mechanisms underlying the development of androgen-independent prostate cancer. Clin Cancer Res 12: 1665-1671, 2006.

3 de Bono JS, Oudard S, Ozguroglu M, Hansen S, Machiels JP, Kocak I, Gravis G, Bodrogi I, Mackenzie MJ, Shen L, Roessner M, Gupta S and Sartor AO: Prednisone plus cabazitaxel or mitoxantrone for metastatic castration-resistant prostate cancer progressing after docetaxel treatment: a randomised open-label trial. Lancet 376: 1147-1154, 2010.

4 Kantoff PW, Higano CS, Shore ND, Berger ER, Small EJ, Penson DF, Redfern CH, Ferrari AC, Dreicer R, Sims RB, Xu Y, Frohlich MW and Schellhammer PF: Sipuleucel-T immunotherapy for castration-resistant prostate cancer. $\mathrm{N}$ Engl J Med 363: 411-422, 2010.

5 Fizazi K, Scher HI, Molina A, Logothetis CJ, Chi KN, Jones RJ, Staffurth JN, North S, Vogelzang NJ, Saad F, Mainwaring P, Harland S, Goodman OB, Jr., Sternberg CN, Li JH, Kheoh T, Haqq $\mathrm{CM}$ and de Bono JS: Abiraterone acetate for treatment of metastatic castration-resistant prostate cancer: final overall survival analysis of the COU-AA-301 randomised, double-blind, placebocontrolled phase 3 study. Lancet Oncol 13: 983-992, 2012.

6 Scher HI, Fizazi K, Saad F, Taplin ME, Sternberg CN, Miller K, de Wit R, Mulders P, Chi KN, Shore ND, Armstrong AJ, Flaig TW, Flechon A, Mainwaring P, Fleming M, Hainsworth JD, Hirmand M, Selby B, Seely L, de Bono JS and Investigators A: Increased survival with enzalutamide in prostate cancer after chemotherapy. N Engl J Med 367: 1187-1197, 2012.

7 Parker C, Nilsson S, Heinrich D, Helle SI, O'Sullivan JM, Fossa SD, Chodacki A, Wiechno P, Logue J, Seke M, Widmark A, Johannessen DC, Hoskin P, Bottomley D, James ND, Solberg A, Syndikus I, Kliment J, Wedel S, Boehmer S, Dall'Oglio M, Franzen L, Coleman R, Vogelzang NJ, O'Bryan-Tear CG, Staudacher K, Garcia-Vargas J, Shan M, Bruland OS and Sartor $\mathrm{O}$ : Alpha emitter radium-223 and survival in metastatic prostate cancer. N Engl J Med 369: 213-223, 2013.

8 Beer TM, Armstrong AJ, Rathkopf DE, Loriot Y, Sternberg CN, Higano CS, Iversen P, Bhattacharya S, Carles J, Chowdhury S, Davis ID, de Bono JS, Evans CP, Fizazi K, Joshua AM, Kim CS, Kimura G, Mainwaring P, Mansbach H, Miller K, Noonberg SB, Perabo F, Phung D, Saad F, Scher HI, Taplin ME, Venner PM, Tombal B and Investigators P: Enzalutamide in metastatic prostate cancer before chemotherapy. N Engl J Med 371: 424-433, 2014.

9 Ryan CJ, Smith MR, Fizazi K, Saad F, Mulders PFA, Sternberg CN, Miller K, Logothetis CJ, Shore ND, Small EJ, Carles J, Flaig TW, Taplin M-E, Higano CS, de Souza P, de Bono JS, Griffin TW, De Porre P, Yu MK, Park YC, Li J, Kheoh T, Naini V, Molina A and Rathkopf DE: Abiraterone acetate plus prednisone versus placebo plus prednisone in chemotherapy-naive men with metastatic castration-resistant prostate cancer (COU-AA-302): final overall survival analysis of a randomised, double-blind, placebocontrolled phase 3 study. Lancet Oncol 16: 152-160, 2015.

10 Montgomery RB, Mostaghel EA, Vessella R, Hess DL, Kalhorn TF, Higano CS, True LD and Nelson PS: Maintenance of intratumoral androgens in metastatic prostate cancer: a mechanism for castration-resistant tumor growth. Cancer Res 68 : 4447-4454, 2008.
11 Molina A and Belldegrun A: Novel therapeutic strategies for castration resistant prostate cancer: inhibition of persistent androgen production and androgen receptor mediated signaling. J Urol 185: 787-794, 2011.

12 Attard G, Cooper CS and de Bono JS: Steroid hormone receptors in prostate cancer: a hard habit to break? Cancer Cell 16: 458-462, 2009.

13 Ryan CJ, Molina A, Li J, Kheoh T, Small EJ, Haqq CM, Grant RP, de Bono JS and Scher HI: Serum androgens as prognostic biomarkers in castration-resistant prostate cancer: results from an analysis of a randomized phase III trial. J Clin Oncol 31: 2791-2798, 2013.

14 Kanda Y: Investigation of the freely available easy-to-use software 'EZR' for medical statistics. Bone Marrow Transplant 48: 452-458, 2013.

15 de Bono JS, Logothetis CJ, Molina A, Fizazi K, North S, Chu L, Chi KN, Jones RJ, Goodman OB, Jr., Saad F, Staffurth JN, Mainwaring P, Harland S, Flaig TW, Hutson TE, Cheng T, Patterson H, Hainsworth JD, Ryan CJ, Sternberg CN, Ellard SL, Flechon A, Saleh M, Scholz M, Efstathiou E, Zivi A, Bianchini D, Loriot Y, Chieffo N, Kheoh T, Haqq CM and Scher HI: Abiraterone and increased survival in metastatic prostate cancer. N Engl J Med 364: 1995-2005, 2011.

16 Ryan CJ, Smith MR, de Bono JS, Molina A, Logothetis CJ, de Souza P, Fizazi K, Mainwaring P, Piulats JM, Ng S, Carles J, Mulders PF, Basch E, Small EJ, Saad F, Schrijvers D, Van Poppel H, Mukherjee SD, Suttmann H, Gerritsen WR, Flaig TW, George DJ, Yu EY, Efstathiou E, Pantuck A, Winquist E, Higano CS, Taplin ME, Park Y, Kheoh T, Griffin T, Scher HI and Rathkopf DE: Abiraterone in metastatic prostate cancer without previous chemotherapy. N Engl J Med 368: 138-148, 2013.

17 Mostaghel EA, Marck BT, Plymate SR, Vessella RL, Balk S, Matsumoto AM, Nelson PS and Montgomery RB: Resistance to CYP17A1 inhibition with abiraterone in castration-resistant prostate cancer: induction of steroidogenesis and androgen receptor splice variants. Clin Cancer Res 17: 5913-5925, 2011.

18 Yuan X, Cai C, Chen S, Chen S, Yu Z and Balk SP: Androgen receptor functions in castration-resistant prostate cancer and mechanisms of resistance to new agents targeting the androgen axis. Oncogene 33: 2815-2825, 2014.

19 Chen EJ, Sowalsky AG, Gao S, Cai C, Voznesensky O, Schaefer R, Loda M, True LD, Ye H, Troncoso P, Lis RL, Kantoff PW, Montgomery RB, Nelson PS, Bubley GJ, Balk SP and Taplin ME: Abiraterone treatment in castration-resistant prostate cancer selects for progesterone responsive mutant androgen receptors. Clin Cancer Res 21: 1273-1280, 2015.

20 Richards J, Lim AC, Hay CW, Taylor AE, Wingate A, Nowakowska K, Pezaro C, Carreira S, Goodall J, Arlt W, McEwan IJ, de Bono JS and Attard G: Interactions of abiraterone, eplerenone, and prednisolone with wild-type and mutant androgen receptor: a rationale for increasing abiraterone exposure or combining with MDV3100. Cancer Res 72: 21762182, 2012.

21 Chi K, Hotte SJ, Joshua AM, North S, Wyatt AW, Collins LL and Saad F: Treatment of mCRPC in the AR-axis-targeted therapy-resistant state. Ann Oncol 26: 2044-2056, 2015.

22 Kim W, Zhang L, Wilton JH, Fetterly G, Mohler JL, Weinberg V, Morse A, Szmulewitz RZ, Friedlander TW, Fong L, Lin AM, Harzstark AL, Molina A, Small EJ and Ryan CJ: Sequential use of the androgen synthesis inhibitors ketoconazole and 
abiraterone acetate in castration-resistant prostate cancer and the predictive value of circulating androgens. Clin Cancer Res 20: 6269-6276, 2014.

23 Watson PA, Arora VK and Sawyers CL: Emerging mechanisms of resistance to androgen receptor inhibitors in prostate cancer. Nat Rev Cancer 15: 701-711, 2015.

24 Tamae D, Mostaghel E, Montgomery B, Nelson PS, Balk SP, Kantoff PW, Taplin ME and Penning TM: The DHEA-sulfate depot following P450c17 inhibition supports the case for AKR1C3 inhibition in high risk localized and advanced castration resistant prostate cancer. Chem Biol Interact 234: 332-338, 2015.

25 Yano A, Kagawa M, Takeshita H, Okada Y, Morozumi M and Kawakami S: Baseline low serum dehydroepiandrosterone sulfate can predict poor responsiveness to hormone therapy in patients with hormone-naive prostate cancer with skeletal metastases. Int J Urol 24: 861-862, 2017.

26 Miyoshi Y, Uemura H, Umemoto S, Sakamaki K, Taguri M, Suzuki K, Shibata Y, Masumori N, Ichikawa T, Mizokami A, Sugimura Y, Nonomura N, Sakai H, Honma S, Harada M and Kubota Y: Low serum dehydroepiandrosterone examined by liquid chromatography-tandem mass spectrometry correlates with poor prognosis in hormone-naive prostate cancer. Prostate 76: 376-382, 2016.

27 Harshman LC, Wang X, Nakabayashi M, Xie W, Valenca L, Werner L, Yu Y, Kantoff AM, Sweeney CJ, Mucci LA, Pomerantz M, Lee GS and Kantoff PW: Statin use at the time of initiation of androgen deprivation therapy and time to progression in patients with hormone-sensitive prostate cancer. JAMA Oncol 1: 495-504, 2015.

28 Bertaglia V, Tucci M, Vignani F, Buttigliero C, Aroasio E, Berruti A, Scagliotti GV and M DIM: An exploratory analysis of the association between levels of hormones implied in steroid biosynthesis and activity of abiraterone in patients with metastatic castration-resistant prostate cancer. Minerva Urol Nefrol 69: 349-358, 2017.

29 Vermeulen A: Dehydroepiandrosterone sulfate and aging. Ann N Y Acad Sci 774: 121-127, 1995.

30 Nishiyama T, Hashimoto Y and Takahashi K: The influence of androgen deprivation therapy on dihydrotestosterone levels in the prostatic tissue of patients with prostate cancer. Clin Cancer Res 10: 7121-7126, 2004.

31 Hiroshige T, Eguchi Y, Yoshizumi O, Chikui K, Kumagai H, Kawaguchi Y, Onishi R, Hayashi T, Watanabe K, Mitani T, Saito K and Igawa T: Baseline prostate-specific antigen levels following treatment with abiraterone acetate as a prognostic factor in castration-resistant prostate cancer. Oncol Lett 15: 6806-6814, 2018.

32 Ryan CJ, Kheoh T, Li J, Molina A, De Porre P, Carles J, Efstathiou E, Kantoff PW, Mulders PFA, Saad F and Chi KN: Prognostic index model for progression-free survival in chemotherapy-naive metastatic castration-resistant prostate cancer treated with abiraterone acetate plus prednisone. Clin Genitourin Cancer, 2017. doi: 10.1016/j.clgc.2017.07.014. [Epub ahead of print]
33 Schellhammer PF, Chodak G, Whitmore JB, Sims R, Frohlich MW and Kantoff PW: Lower baseline prostate-specific antigen is associated with a greater overall survival benefit from sipuleucel-T in the Immunotherapy for Prostate Adenocarcinoma Treatment (IMPACT) trial. Urology 81: 1297-1302, 2013.

34 Armstrong AJ, Garrett-Mayer ES, Yang YC, de Wit R, Tannock IF and Eisenberger M: A contemporary prognostic nomogram for men with hormone-refractory metastatic prostate cancer: a TAX327 study analysis. Clin Cancer Res 13: 6396-6403, 2007.

35 Bianchini D, Lorente D, Rodriguez-Vida A, Omlin A, Pezaro C, Ferraldeschi R, Zivi A, Attard G, Chowdhury S and de Bono JS: Antitumour activity of enzalutamide (MDV3100) in patients with metastatic castration-resistant prostate cancer (CRPC) pretreated with docetaxel and abiraterone. Eur J Cancer 50: 78-84, 2014.

36 Schrader AJ, Boegemann M, Ohlmann CH, Schnoeller TJ, Krabbe LM, Hajili T, Jentzmik F, Stoeckle M, Schrader M, Herrmann E and Cronauer MV: Enzalutamide in castrationresistant prostate cancer patients progressing after docetaxel and abiraterone. Eur Urol 65: 30-36, 2014.

37 Davies RS, Smith C and Lester JF: Third-line Enzalutamide Following Docetaxel and Abiraterone in Metastatic Castrateresistant Prostate Cancer. Anticancer Res 36: 1799-1803, 2016.

38 Fizazi K, Tran N, Fein L, Matsubara N, Rodriguez-Antolin A, Alekseev BY, Ozguroglu M, Ye D, Feyerabend S, Protheroe A, De Porre P, Kheoh T, Park YC, Todd MB, Chi KN and Investigators L: Abiraterone plus Prednisone in Metastatic, Castration-Sensitive Prostate Cancer. N Engl J Med 377: 352360, 2017.

39 Detti B, D'Angelillo RM, Ingrosso G, Olmetto E, Francolini G, Triggiani L, Bruni A, Borghesi S, Fondelli S, Carfagno T, Santini R, Santoni R, Trodella LE, and Livi L: Combining Abiraterone and Radiotherapy in Prostate Cancer Patients Who Progressed During Abiraterone Therapy. Anticancer Res 37: 3717-3722, 2017.

40 Supiot S, Campion L, Pommier P, Dore M, Palpacuer C, Racadot S, Rio E, Milano GA, Mahier-Ait Oukhatar C and Carrie C: Combined abiraterone acetate plus prednisone, salvage prostate bed radiotherapy and LH-RH agonists (CARLHAGEP12) in biochemically-relapsing prostate cancer patients following prostatectomy: A phase I study of the GETUG/GEP. Oncotarget 9: 22147-22157, 2018.

41 Cho E, Mostaghel EA, Russell KJ, Liao JJ, Konodi MA, Kurland BF, Marck BT, Matsumoto AM, Dalkin BL and Montgomery RB: External beam radiation therapy and abiraterone in men with localized prostate cancer: safety and effect on tissue androgens. Int J Radiat Oncol Biol Phys 92: 236$243,2015$.
Received August 27, 2018

Revised September 15, 2018 Accepted September 17, 2018 